\title{
TOR1A Gene
}

National Cancer Institute

\section{Source}

National Cancer Institute. TOR1A Gene. NCI Thesaurus. Code C142757.

This gene plays a role in post-translational processing of proteins. 